\title{
Marek Świerczyński*
}

\section{Naruszenie patentu na drugie zastosowanie medyczne w świetle systemu refundacyjnego}

\section{Spis treści}

I. Wprowadzenie

II. Istota drugiego zastosowania medycznego

III. Geneza drugiego zastosowania medycznego w europejskim prawie patentowym

IV. Naruszenie patentu na drugie zastosowanie medyczne

V. System refundacyjny

VI. Przykład substytucji aptecznej

VII. Orzeczenia angielskie

VIII. Orzeczenie holenderskie

IX. Ocena orzeczeń w świetle systemu refundacyjnego

X. Wnioski

\section{Streszczenie}

Opracowanie poświęcone jest problematyce naruszenia drugiego medycznego zastosowania w świetle systemu refundacyjnego. Inspiracją do napisania artykułu były dwa niedawne rozbieżne orzeczenia sądów obcych. Sądy te rozważały czy sprzedaż leków odtwórczych z oficjalnymi (określonymi na ulotce) wskazaniami do zastosowania w zakresie nieobjętym patentem może zostać uznana za naruszenie patentu dotyczącego drugiego medycznego zastosowania w sytuacji, gdy z okoliczności sprawy wynikało, że leki te były faktyczne stosowane we wskazaniach objętych tym patentem (tj. off-label - poza wskazaniami zarejestrowanymi dla tego leku). Sądy oparły się na odmiennej argumentacji prawnej, co doprowadziło do wydania rozbieżnych rozstrzygnięć. W nawiązaniu do tych orzeczeń zamierzeniem autora opracowania jest udzielenie odpowiedzi na następujące pytanie - czy celowe jest ograniczenie zakresu patentu na drugie zastosowanie medyczne, w przypadku gdy leki oparte na danej substancji podlegają refundacji, w celu zapewnienia szerszego dostępu do tych leków pacjentom.

Słowa kluczowe: wynalazek; patent; produkty lecznicze; refundacja.

JEL: K32. 


\section{Wprowadzenie}

Opracowanie poświęcone jest problematyce naruszenia patentu na drugie zastosowanie medyczne ${ }^{1}$ w świetle systemu refundacyjnego. Inspiracją do napisania artykułu stały się rozbieżne orzeczenia sądów angielskich i holenderskich. Sądy te rozważały czy sprzedaż leków odtwórczych² z oficjalnymi (określonymi na ulotce) wskazaniami do zastosowania w zakresie nieobjętym patentem może zostać uznana za naruszenie patentu dotyczącego drugiego medycznego zastosowania w sytuacji, gdy z okoliczności sprawy wynikało, że leki te były faktyczne sprzedawane i stosowane w innych wskazaniach objętych tym patentem (tj. off-label - poza oficjalnymi zarejestrowanymi wskazaniami dla tego leku). Sądy oparły się na odmiennej argumentacji prawnej, co doprowadziło do wydania rozbieżnych rozstrzygnięć.

Powyższe zagadnienie wymaga dodatkowej analizy w świetle specyfiki systemu refundacyjnego ${ }^{3}$, które nakłada na farmaceutów obowiązek zamiennictwa leków w celu obniżenia kosztów refundacji oraz zachęca szpitale do nabywania tańszych zamienników w przetargach publicznych. Aktualność tematu wynika z niedawnych nowelizacji zarówno prawa własności przemysłowej, która objęła patentowalność wynalazku polegającego na drugim zastosowaniu medycznym znanej substancji, jak i polskiej regulacji refundacyjnej w zakresie zamiennictwa aptecznego. Uwzględnić należy również oczekiwane wejście w życie systemu jednolitego patentu unijnego ${ }^{4}$. W tym kontekście zasadne jest w udzielenie odpowiedzi na następujące pytanie - czy celowe jest ograniczenie zakresu patentu na drugie zastosowanie medyczne ${ }^{5}$, w przypadku gdy tańszy zamiennik podlega refundacji, w celu umożliwienia wykorzystania tego zamiennika w tym wskazaniu 6 . Trudność w udzieleniu odpowiedzi na powyższe pytanie wynika z tego, że, jak trafnie zaznacza A. Nowicka, niezmiernie trudne jest wyważenie sprzecznych interesów w dziedzinie ochrony innowacji farmaceutycznych (Nowicka, 2005).

\section{Istota drugiego zastosowania medycznego}

Możliwość opatentowania wynalazku związanego z drugim medycznym zastosowaniem (second medical use) polega na tym, że substancja o znanych już właściwościach terapeutycznych może być przeznaczona do innego, nowego i nieoczywistego zastosowania terapeutycznego (Żakowska-Henzler, 2001). Zdarza się, że kolejne zastosowania medyczne mają nawet większą użyteczność, aniżeli pierwsze wynalezione zastosowanie (Cook, 2016, s. 99), co wynika w szczególności z faktu, że substancja aktywna została w większym stopniu zbadana (Nowicka, 2005, s. 680). Rodzi to jednak komplikacje praktyczne w przypadku, gdy patent na pierwsze zastosowanie medyczne już wygasł, a do obrotu wprowadzone zostały leki odtwórcze (zamienniki). Jest oczywiste, że, ze względu na ograniczenia wynikające z prawa patentowego, leki te nie mogą zostać zarejestrowane i stosowane w drugim medycznym zastosowaniu, zatem ich sprzedaż

\footnotetext{
Analogicznie dla kolejnych zastosowań medycznych. Dla uproszczenia wywodów będę się posługiwać pojęciem „drugiego zastosowania medycznego", mając na uwadze także kolejne zastosowania medyczne.

2 Tym pojęciem będę się posługiwać, gdy chodzi o leki generyczne oraz biopodobne.

3 Ustawa z dnia 12.05.2011 r. o refundacji leków, środków spożywczych specjalnego przeznaczenia żywieniowego oraz wyrobów medycznych (t.j. Dz.U. 2015, poz. 345 ze zm.); dalej: ustawa refundacyjna.

4 O negatywnych skutki pakietu pisze S. Sołtysiński (2014, s. 182).

Ewentualnie czy ograniczenie patentu miałoby wynikać z takich klauzul, jak porządek publiczny (ordre public), zasady współżycia społecznego czy moralność (w polskich realiach art. 5 k.c.) (por. Aplin i Davis, 2013, s. 615-619; Grabowski, 2002, s. 10 i n.).

6 W szczególności, gdy chodzi o leki dotyczące chorób o zasięgu globalnym. W piśmiennictwie zwrócono uwagę na możliwość pogodzenia sprzecznych celów prawa patentowego i prawa konkurencji (zob. Lanjouw, 2002, s. 86-123).
} 
w celu stosowania ich w takim wskazaniu musiałaby zostać uznana za naruszenie patentu. Jednakże w praktyce medycznej powszechny jest przypadek stosowania leku off-label, kiedy to lekarz podejmuje decyzję o przepisaniu danego leku poza zakresem jego zarejestrowanych wskazań medycznych. W tym celu zamienniki mogą być nabywane przez szpitale bądź wydawane w aptekach przez farmaceutów. Powodem zamiennictwa jest niższa cena leku odtwórczego. Powstaje w związku z tym pytanie - czy, pomimo obowiązywania patentu, zamiennik może być stosowany również w drugim wskazaniu medycznym, skoro zawiera on taką samą substancję, co lek oryginalny. Co więcej, system refundacyjny zachęca do przepisywania i sprzedaży tańszych zamienników leków. W praktyce zdarza się, że farmaceuta proponuje pacjentowi lek odtwórczy zawierający tę samą substancję aktywną, ze względu na jego niższą cenę. $Z$ tych samych powodów zakupem zamienników zainteresowane są szpitale. Z punktu widzenia prawa własności intelektualnej powstaje wtedy pytanie - czy producent leku oryginalnego może zarzucić konkurentowi - producentowi leku odtwórczego, szpitalowi bądź farmaceucie naruszenie patentu oraz czy podjęcie przez uprawnionego z patentu związanych z tym działań prawnych może być traktowane jako nadużycie patentu ${ }^{7}$ ?

\section{Geneza drugiego zastosowania medycznego w europejskim prawie patentowym}

W systemie patentu europejskiego opartego na konwencji monachijskiej8 możliwość opatentowania drugiego zastosowania medycznego została potwierdzona w 1984 r., kiedy Rozszerzona Komisja Odwoławcza Europejskiego Urzędu Patentowego wydała decyzję w sprawie Eisai oraz orzekła w sześciu innych sprawach, których wspólnym przedmiotem było dopuszczenie patentowania drugiego medycznego zastosowania ${ }^{9}$. Rozstrzygnięcie to jest uznawane za trafne. Podkreśla się, że decyzja Eisai wypełniła istotną lukę w systemie patentowym ${ }^{10}$.

W praktyce patentowej wykorzystywana była tzw. szwajcarska metoda formułowania zastrzeżeń patentowych (Swiss claims). Zastrzeżenia patentowe wyrażane były w postaci następującej: „zastosowanie substancji $X$ do wytworzenia leku o wskazanym, nowym i wynalazczym zastosowaniu terapeutycznym"11. Zastrzeżenia dotyczące drugiego medycznego zastosowania według metody szwajcarskiej zawierały zatem trzy elementy: a) odniesienie do znanej substancji; b) użycie tej substancji do wytworzenia leku oraz c) nowe zastosowanie terapeutyczne tego leku (szerzej: Pacud, 2013, s. 142-154). Sformułowanie „zastosowanie substancji X do wytworzenia leku” jest przy tym uznawane za równoznaczne z pojęciem „wytworzenia leku przy użyciu sub-

Chodzi np. o sytuację, gdy występowanie z żądaniem zaniechania korzystania z wynalazku mogłoby być traktowane jako nadużycie pozycji dominującej przez uprawnionego z patentu w rozumieniu art. 9 ustawy o ochronie konkurencji i konsumentów oraz art. 102 TFUE (por. SzczepanowskaKozłowska, 2015, s. 459). Na temat rodzajów możliwych kolizji prawa patentowego z prawem konkurencji, ze szczególnym uwzględnieniem przypadku nadużycia strategii patentowych zob. szerzej: Rubinfeld i Maness, (2005, s. 85-101).

8 Konwencja o udzielaniu patentów europejskich (Konwencja o patencie europejskim), sporządzona w Monachium dnia 5 października 1973 r., zmieniona aktem zmieniającym artykuł 63 Konwencji z dnia 17 grudnia 1991 r. oraz decyzjami Rady Administracyjnej Europejskiej Organizacji Patentowej z dnia 21 grudnia 1978 r., 13 grudnia 1994 r., 20 października 1995 r., 5 grudnia 1996 r. oraz 10 grudnia 1998 r., wraz z protokołami stanowiącymi jej integralną część (Dz.U. 2004 Nr 79, poz. 737) (zob. szerzej: Aplin i Davis, 2013, s. 554-555).

9 G-05/83 Second medical indication/EISAI [1985] OJEPO 64; [1979-85] EPOR B 241; Cook, (2016, s. 99); szerzej: Pacud, (2013, s. 142-154).

10 G-02/08 Dosage Regime/ABBOTT RESPIRATORY (Enlarged Board of Appeal, 19 February 2010) [2010] OJEPO 456. Por. pkt 5.9, 5.10.2, 7.1.1 uzasadnienia decyzji Rozszerzonej Komisji Odwoławczej G-02/88 Friction Reducing Additive/MOBIL OIL III [1990] OJEPO 93. Podobnie w sprawie G-06/88 Plant growth regulating agent/BAYER (Rozszerzona Komisja Odwoławcza, 11 grudnia 1989 r.). Zob. szerzej Case Law of the Boards of Appeal of the European Patent Office (7th Edition), EPO, September 2013, s. 154-162.

Przykład: w sprawie T-0128/82 Pyrrolidinederivatives/HOFFMAN-LA ROCHE: zastrzeżenia przyjęły brzmienie „Pyrrolidine derivatives having [a certain general formula] for use as an active therapeutic substance." - [1984] OJEPO 164; [1979-85] EPOR B 591. 
stancji X" (Pacud, 2013, s. 142-154). W konsekwencji ochrona patentowa rozciąga się również na lek wytworzony bezpośrednio tym sposobem.

Na podstawie aktu rewidującego z 2000 r. do konwencji monachijskiej wprowadzone zostały zmiany dotyczące drugiego medycznego zastosowania, tak aby nie ulegało wątpliwości dopuszczenie patentowania tego rodzaju wynalazków bezpośrednio na podstawie brzmienia tego aktu prawnego (Cook, 2016, s. 97). Do konwencji dodany został nowy art. 54 ust. 5, który jednoznacznie przewiduje możliwość patentowania drugiego medycznego zastosowania za pomocą zastrzeżenia w formie product-by-use, co stanowi rozwiązanie analogiczne do stosowanego w przypadku pierwszego zastosowania medycznego (art. 54 ust. 4 konwencji monachijskiej). Brzmienie przepisu jest następujące: „ustępy 2 i 3 nie wyłączają również zdolności patentowej jakiejkolwiek substancji lub mieszaniny, o której mowa w ustępie 4 stosowanej w ściśle określony sposób w jakiejkolwiek metodzie, której mowa w art. 53 lit. c, pod warunkiem że takie zastosowanie nie jest objęte stanem techniki". Ingerencja ustawodawcza stanowi potwierdzenie wcześniejszego stanu rzeczy ${ }^{12}$. Co istotne dla leków, omawiana regulacja obejmuje także przypadek rozszerzenia wyłączności na drodze dodatkowego świadectwa ochronnego SPC (supplementary protection certificate) ${ }^{13}$.

Należy podkreślić, że celem art. 54 ust. 5 konwencji monachijskiej jest dopuszczenie ochrony patentowej na znaną substancję lub jej mieszaninę wtedy, gdy ma ona nowe zastosowanie w sposobach leczenia (medical use) (Nowicka, 2005, s. 679). W konsekwencji wejście w życie nowych przepisów ograniczyło potrzebę sięgania do metody szwajcarskiej, ponieważ taki sposób sformułowania zastrzeżeń patentowych nie jest już potrzebny. Tym samym ułatwione zostało uzyskiwanie ochrony znanych substancji w zakresie ich nowego zastosowania. Co więcej oznacza to w praktyce poszerzenie zakresu ochrony. W świetle nowych przepisów dopuszczalne jest udzielenie patentu nie tylko na pierwsze, lecz także każde kolejne nowe zastosowania znanej substancji (Nowicka, 2005, s. 680). Ponadto zgodnie z decyzją Rozszerzonej Komisji Odwoławczej w sprawie G-02/08 Dosage Regime/Abbott Respiratory ${ }^{14}$, stosowanie szwajcarskiej metody nie jest już dopuszczalne (z zastrzeżeniem, że decyzja nie ma wstecznego skutku dla patentów już udzielonych według tej metody).

Analogiczne do przepisów konwencji monachijskiej zmiany zostały wprowadzone w odniesieniu do krajowych patentów na mocy nowelizacji pwp z 2015 r. ${ }^{15}$. Począwszy od dnia 1 grudnia 2015 r. ust. 4 art. 25 pwp otrzymał brzmienie: „4. Przepisy ust. 1-3 nie wyłączają możliwości udzielenia patentu na wynalazek dotyczący substancji lub mieszanin stanowiących część stanu techniki do zastosowania lub zastosowania w ściśle określony sposób w sposobach leczenia lub diagnostyki, o których mowa w art. 29 ust. 1 pkt 3, pod warunkiem że takie zastosowanie nie stanowi części stanu techniki”. Nowelizacja ta była niezbędna ze względu na konieczność odejścia od narzucania zgłaszającemu specyficznej metody formułowania zastrzeżeń patentowych na

\footnotetext{
Rozszerzona Komisja Odwoławcza przyjęła w decyzji G 2/08, że zasady ustanowione w decyzjach Europejskiego Urzędu Patentowego zachowują aktualność w odniesieniu do przepisów dotyczących zastosowań medycznych według zmienionej konwencji - Decyzja G 2/08, pkt 5.10.8.

13 Instytucja SPC została ustanowiona w UE w 1992 r. w celu zrekompensowania skrócenia efektywnej wyłączności rynkowej, które wynika z potrzeby przeprowadzenia badań niezbędnych dla uzyskania pozwolenia na dopuszczenie leku do obrotu. Zob. rozporządzenie Rady (UE) 1769/92 z dnia 18 czerwca 1992 r. o stworzeniu dodatkowego świadectwa ochronnego dla produktów leczniczych (O.J. L 182 z 2 lipca 1992 r., s. 1). Wprowadzony do polskiego porządku prawnego na mocy art. 2 ustawy z dnia 6 czerwca 2002 r. nowelizującej prawo własności przemysłowej. Rozdział $5^{1}$, zatytułowany „dodatkowe prawo ochronne” - art. 751-75 ${ }^{10}$ weszły w życie wraz z przystąpieniem Polski do Unii Europejskiej (zob. szerzej: Nowicka, 2009, s. 73-97; 2004; Katzka, 2008, s. 650 i n. oraz orzecznictwo TSUE, np. w sprawie C-482/07).

14 G-02/08 Dosage Regime/ABBOTT RESPIRATORY (Enlarged Board of Appeal, 19 February 2010) [2010] OJEPO 456.

15 Ustawa z dnia 24.07.2015 r. o zmianie ustawy - Prawo własności przemysłowej oraz niektórych innych ustaw (Dz.U. 2015, poz. 1266). Ustawa z dnia 30 czerwca 2000 r. - Prawo własności przemysłowej (t.j. Dz.U. 2003 Nr 119, poz. 1117 z późn. zm.); dalej: pwp.
} 
kolejne zastosowania znanych substancji lub kompozycji tzw. metody szwajcarskiej. Stosowanie nowych przepisów w odniesieniu do leków objętych systemem refundacyjnym w ocenie autora opracowania będzie stanowić jedno z ważniejszych wyzwań w dziedzinie life sciences, ze względu na powody podane poniżej.

\section{Naruszenie patentu na drugie zastosowanie medyczne}

Warto zadać pytanie, kiedy w praktyce medycznej może dojść do naruszenia patentu odnoszącego się do drugiego zastosowania medycznego danego leku? Jak już wcześniej wskazano, dana substancja aktywna objęta takim patentem może być wprowadzana do obrotu przez konkurentów uprawnionego z patentu, w sytuacji gdy patent na pierwsze zastosowanie medyczne już wygasł. Najprostszym przypadkiem naruszenia patentu będzie przypadek, gdy konkurent wprost wskaże drugie zastosowanie medyczne sprzedawanego leku w Charakterystyce Produktu Leczniczego, na ulotce dla pacjenta oraz w materiałach handlowych bądź reklamie ${ }^{16}$.

Z orzecznictwa niemieckiego wynika, że do bezpośredniego naruszenia patentu dochodzi wówczas, gdy z charakterystyki produktu leczniczego bądź ulotki przeznaczonej dla pacjenta w sposób oczywisty wynika, że konkurencyjny lek jest przeznaczony do zastosowania we wskazaniu objętym patentem ${ }^{17}$. Takie oznaczenie leku bądź jego opakowania nie jest jednak konieczne dla stwierdzenia naruszenia patentu. Wystarczy bowiem, że ze składu, dawki bądź gotowych formuł przygotowania leku w celu leczenia pacjentów pośrednio wynika takie jego przeznaczenie. Warunkiem jest jednak to, aby okoliczności te były ściśle powiązane z tym konkretnym lekiem.

W prawie angielskim zagadnienie naruszenia patentu w zakresie drugiego zastosowania medycznego zostało doprecyzowane w orzeczeniu w sprawie Grimme Maschinenfabrik p. Derek Scott [2010] EWCA Civ 1110. Wynika z niego zasada, że osobą odpowiedzialną za naruszenie patentu jest ten, kto dostarcza istotnych środków (essentials means) umożliwiających ostatecznym użytkownikom wynalazku podjęcie działań skutkujących naruszeniem.

Z perspektywy polskiego prawa patentowego należy przyjąć, że producent leku odtwórczego poniesie odpowiedzialność z tytułu naruszenia patentu, jeżeli wie albo powinien był wiedzieć, co musi jasno wynikać z okoliczności sprawy, że lek był przeznaczony dla jego wykorzystania w zakresie objętym patentem (czyli drugim zastosowaniu medycznym). Stwierdzenia, że doszło do naruszenia patentu nie zmienia fakt skutecznej rejestracji leku odtwórczego (tj. uzyskania pozwolenia na dopuszczenie do obrotu) bądź objęcia tego leku refundacją. Działania te, choć z reguły potwierdzane stosownymi decyzjami administracyjnymi, nie mogą bowiem legitymizować omawianej działalności i prowadzić do wniosku, że do naruszenia patentu nie doszło.

Analogicznie nie można wykluczyć odpowiedzialności właściciela hurtowni bądź apteki z tytułu naruszenia patentu zarówno w sytuacji, gdy sprzedaje on lek odtwórczy zarejestrowany we wskazaniu objętym patentem, jak i gdy oferuje go dla leczenia w danym wskazaniu (np. dostarczając lek w przetargu szpitalnym dotyczącym tego wskazania), nawet jeśli lek nie został zarejestrowany w tym wskazaniu (chodzi więc o jego zastosowanie off-label). Szczególnym przypadkiem jest dokonanie zamiany (substytucji) leku w aptece przez farmaceutę. Problem ten jest istotny ze

\footnotetext{
O naruszeniu patentu w świetle konwencji monachijskiej zob. Aplin i Davis (2013, s. 715-716).

7 Zob. Düsseldorf District Court, docket number 4a 0 12/03, 24 February 2004, GRUR-RR 2004, 193 - Ribavirin; Düsseldorf Court of Appeal, docket number 2 U 54/11, 31 January 2013 - Cistus Incanus; Düsseldorf District Court, docket number 4a O 145/12, 14 March 2013 - Chronic Hepatitis C.
} 
względu na obowiązki w zakresie kamiennictwa nałożone na farmaceutę. Powstaje w związku z tym pytanie o relację przepisów refundacyjnych do prawa własności intelektualnej.

\section{System refundacyjny}

W Polsce zasady refundacji leków, wyrobów medycznych oraz środków spożywczych specjalnego przeznaczenia żywieniowego określa od 1 stycznia 2012 r. ustawa refundacyjna. Głównym celem nowej ustawy było prawidłowe wdrożenie unijnej dyrektywy przejrzystości cen ${ }^{18}$, co polegało przede wszystkim na wprowadzeniu mechanizmu indywidualnych decyzji refundacyjnych, określających ceny leków oraz warunki ich refundacji (Jacek, 2013, s. 109 i n.). Terminowość decyzji ma wymuszać cykliczną weryfikację zasadności finansowania leków (Jacek, 2013, przyp. 39, s. 115).

Należy zwrócić uwagę, że system refundacji obejmuje leki, których wykaz jest zamieszczany w specjalnych obwieszczeniach (tzw. wykazach leków refundacyjnych), aktualizowanych co dwa miesiące (Jacek, 2013, przyp. 39, s. 116). W orzecznictwie podkreślono, że obwieszczeń nie można zaliczyć do aktów stosowania prawa, ale jego stanowienia19.

Ustawa refundacyjna realizuje zasadę „im taniej, tym lepiej” a zasady prawa patentowego nie znajdują w niej właściwego odzwierciedlenia. Ochrona patentowa leków nie może jednak pozostawać w oderwaniu od faktycznej możliwości sprzedaży leku. Mechanizm refundacji produktów leczniczych ma ponadto znaczenie dla dochodzenia roszczeń z tytułu naruszenia patentów. System ten może w większym albo mniejszym stopniu uwzględniać ograniczenia wynikające z patentów, jak również sugerować metody obejścia systemu patentowego. Dotyczy to m.in. zagadnienia zasad preskrypcji leków. Chodzi tu o rozstrzygnięcie czy, przykładowo, przepisywane mają być konkretne leki, tj. czy na recepcie ma być wpisywana ich nazwa handlowa, czy też powinna być to nazwa samej substancji czynnej. Istotne są również wskazania lecznicze, np. czy lek ma zostać zastosowany off-label, a więc poza zarejestrowanymi wskazaniami. Problemy te ilustruje najnowsze orzecznictwo sądowe angielskie oraz holenderskie. Warto się im przyjrzeć w celu stwierdzenia, z jakimi problemami możemy się spotkać w Polsce, mając na uwadze specyfikę polskiego systemu refundacji leków. W pierwszej kolejności warto jednak przyjrzeć się bliżej problemowi polskiej substytucji aptecznej.

\section{Przykład substytucji aptecznej}

Zamiennictwo (substytucja) apteczna jest zagadnieniem wywołującym istotne problemy praktyczne. Cel wprowadzenia przepisów o zamiennictwie w ustawie refundacyjnej jest słuszny. Chodzi o obniżenie kosztów leków zarówno w kontekście obciążeń budżetu refundacyjnego państwa, jak i wysokości dopłaty ponoszonej przez pacjenta. Gdy chodzi o drugie zastosowanie medyczne, warto jednak zastanowić się nad przypadkiem zamiennictwa off-label, czyli wydania leku poza zakresem zarejestrowanych wskazań.

Ustawa refundacyjna nakładana na farmaceutów obowiązek poinformowania pacjenta o możliwości substytucji (art. 44 ustawy refundacyjnej). Pojawia się pytanie - czy obowiązek ten ulega ograniczeniu bądź wyłączeniu ze względu na ochronę patentową leku przepisanego na recepcie.

\footnotetext{
18 M. Pieklak, R. Stankiewicz, M. Czarnuch, M. Mądry, (przyp. 9), komentarz do art. 11 (w:) Stankiewicz R. i Pieklak M. (red.) (2014). Ustawa o refundacji leków, środków spożywczych specjalnego przeznaczenia żywieniowego oraz wyrobów medycznych. Komentarz. C.H. Beck. Legalis/el.

19 Postanowienie NSA z 28 listopada 2012 r., II GSK 1662/12, LEX nr 1240602.
} 
W szczególności chodzi o sytuację, gdy tzw. drugie zastosowanie medyczne leku przepisanego na recepcie jest objęte taką ochroną a zamiennik miałby zostać zastosowany off-label.

W świetle art. 44 ustawy refundacyjnej farmaceuta zobowiązany jest poinformować pacjenta o możliwości nabycia leku objętego refundacją, innego niż lek przepisany na recepcie, który stanowi jego odpowiednik i ma niższą cenę. Ponadto farmaceuta ma zapewnić dostępność zamiennika oraz wydać go na żądanie pacjenta. Jest to jeden z mechanizmów ustawy refundacyjnej mających na celu obniżenie stopnia wydatkowania środków publicznych w ramach systemu refundacji.

W ocenie autora niniejszej publikacji jest oczywiste, że przepis ten nie może nakładać obowiązku prawnego na farmaceutę skutkującego sprzedażą zamiennika prowadzącą do naruszenia prawa patentowego. Przestrzeganie prawa patentowego obowiązuje wszystkich uczestników obrotu, nie tylko więc producentów zamienników, lecz także osób prowadzących nimi obrót.

Należy podkreślić, że zastosowanie leku off-label ma określone konsekwencje prawne. Zasadą jest, że produkty lecznicze muszą być stosowane ściśle z Charakterystyką Produktu Leczniczego. Prawo daje tylko lekarzowi (ale już nie farmaceucie) prawo do stosowania produktów leczniczych off-label, poza ściśle określoną rejestracją, w ramach dołożenia należytej staranności w procesie leczenia ${ }^{20}$ oraz w poszanowaniu przepisów prawa własności intelektualnej. Decyzji lekarza o zastosowaniu leku off-label nie może jednak zastąpić farmaceuta, działający w ramach mechanizmu ustawowej substytucji. Z punktu widzenia interesów zdrowotnych pacjenta nie bez znaczenia jest także wyłączenie odpowiedzialności producenta zamiennika w przypadku stosowania tego leku off-label.

Powstaje ponadto pytanie o wpływ ostatnich zmiany prawnych w zakresie substytucji leków na odpowiedzialność z tytułu naruszenia. Z dniem 12 czerwca 2016 r. nowelizacja ustawy o świadczeniach opieki zdrowotnej finansowanych ze środków publicznych oraz niektórych innych ustaw (Dz.U. 2016, poz. 652) dokonała rozszerzenia art. 44 ust. 2 i 3 ustawy refundacyjnej. Na jej podstawie, farmaceuta jest uprawniony, o ile lekarz nie dokonał adnotacji zakazującej zamiany, wydać na żądanie pacjenta (po wcześniejszym jego poinformowaniu o możliwości nabycia tańszego leku):

- $\quad$ lek o cenie równej lub wyższej niż cena leku zapisanego na recepcie;

- lek nierefundowany ze $100 \%$ odpłatnością (także po spełnieniu w/w obowiązku);

- opakowanie różniące się o maksymalnie 10\% liczbę dawek w stosunku do opakowania zapisanego.

Powyższe oznacza, że farmaceuta może wydawać odpowiedniki zarówno tańsze, jak i droższe oraz w równej cenie w stosunku do leku przepisanego na recepcie. Zmiana podejścia, choć niewątpliwie pożądana w zakresie dostępności leków dla pacjenta, nie zmienia jednak przedstawionych wyżej reguł odpowiedzialności z tytułu potencjalnego naruszenia patentu przez farmaceutę. Prowadzić będzie równocześnie do zwiększenia skali substytucji aptecznej, a co za tym zwiększonej do kolizji prawa patentowego z systemem refundacyjnym. Zagadnienie to warto przeanalizować w kontekście najnowszych wyroków sądów obcych.

\footnotetext{
20 Przykłady: 1) zastosowanie produktu off-label wynika z konieczności ratowania życia pacjenta lub ochrony przed wystąpieniem ciężkiego rozstroju zdrowia; 2) w trakcie procesu leczenia wykorzystano wszelkie dostępne i zarejestrowane w danym wskazaniu produkty lecznicze; 3) dotychczasowa terapia okazała się nieskuteczna; 4) wynik leczenia okazał się niezadawalający; 5) zastosowanie produktu off-labe/ wpływa na wyeliminowanie lub zmniejszenie ryzyka zdrowotnego u pacjenta. Sąd Apelacyjny w Lublinie, wskazał, że „do obowiązków lekarzy oraz personelu medycznego należy podjęcie takiego sposobu postępowania (leczenia), które gwarantować powinno, przy zachowaniu aktualnego stanu wiedzy i zasad staranności, przewidywalny efekt w postaci wyleczenia, a przede wszystkim nie narażanie pacjentów na pogorszenie stanu zdrowia" (Orzeczenie SA w Lublinie z 29.09.2005 r., sygn. I ACa 510/05).
} 


\section{Orzeczenia angielskie}

Dwa orzeczenia sądu angielskiego w sprawie Warner-Lambert Company, LLC p. Actavis Group PTC EHF \& Others, pierwsze ze stycznia 2015 r. [2015] EWHC 72 (Pat) a drugie WarnerLambert p. Actavis [2015] EWHC 223 (Pat) dotyczyły udzielenia tymczasowego zabezpieczenia na rzecz uprawnionego Warner-Lambert. Sprawa związana była ze stosowaniem leku na receptę pregabalin (Lyrica), wykorzystywanego do leczenia epilepsji (padaczki), ogólnych zaburzeń lękowych (generalised anxiety disorder) oraz bólu neuropatycznego. Wszystkie patenty oraz dodatkowe świadectwa ochronne (SPC) chroniące pregabalin wygasły, z wyjątkiem drugiego zastosowania medycznego obejmującego zastosowanie substancji pregabalin do wytworzenia leku dla celów leczenia bólu (wykorzystano metodę szwajcarską formułowania zastrzeżeń patentowych). Konkurencyjna spółka generyczna Actavis planowała wprowadzenie na rynek własnego generycznego leku (Lecaent) opartego na tej samej substancji, przy czym w ulotkach ograniczono jego wykorzystanie jedynie do dwóch wskazań nie objętych patentem.

Powód - uprawniony z patentu - spółka Warner-Lambert podniósł, że samo wprowadzenie leku generycznego na rynek skutkuje ekonomiczną zachętą, aby stosować go we wszystkich wskazaniach - zarówno zarejestrowanych, jak i niezarejestrowanych. Zaznaczył, że recepty są zazwyczaj przepisywane w sposób ogólny, bez określenia konkretnych wskazań, a cena leku generycznego jest niższa. Zażądał nałożenia na Actavis obowiązków polegających na wprowadzeniu w umowach z dostawcami obowiązku, aby ci odpowiednio oznaczali dostawy leku Lecaent oraz bezpośrednio informowali organizacje ochrony zdrowia o ograniczeniach w dozwolonym stosowaniu leku Lecaent.

Sąd angielski orzekł, że szwajcarska metoda formułowania zastrzeżeń patentowych zapewnia jedynie wyłączność prawną w odniesieniu do sposobu wytwarzania produktu leczniczego (process claims for the method of preparation of a pharmaceutical product). Tymczasem pośrednicy oraz farmaceuci nie będą używać produktu Lecaent dla celów wytwarzania leków. Zdaniem sądu, metoda szwajcarska wymaga od Actavis (jako wytwórcy) zamierzonego użycia leku Lecaent dla leczenia bólu, aby można było przyjąć naruszenie patentu. Tymczasem intencje Actavis nie były przedmiotem pozwu, jak i nie wynikały z przedstawionych przez powoda dowodów. W konsekwencji sąd angielski odmówił udzielenia zabezpieczenia na rzecz spółki Warner-Lambert.

\section{Orzeczenie holenderskie}

W Holandii, w okresie pomiędzy dwoma przedstawionymi powyżej orzeczeniami w sprawie Warner-Lambert, sąd apelacyjny w Hadze wydał orzeczenie w sprawie Novartis AG p. Sun Pharmaceutical Industries (Europe) $B V^{21}$. Sprawa dotyczyła leku zawierającego substancję czynną w postaci kwasu zoledronowego (Aclasta) wytwarzanego przez Novartis, wykorzystywanego dla leczenia osteoporozy. Wskazanie to jest przedmiotem patentu dla drugiego zastosowania medycznego opisanego według metody szwajcarskiej. Patent nie obejmował natomiast leczenia rzadko występującej choroby Pageta. Wprowadzany na rynek przez konkurenta spółkę Sun Pharmaceutical Industries lek generyczny zawierający kwas zoledronowym miał natomiast służyć wyłącznie leczeniu choroby Pageta.

21 (C/09/460540 / KG ZA) Case file number: 200.150.713/01. Novartis AG v. Sun Pharmaceutical Industries (Europe) BV, preliminary injunction case before the District Court of The Hague, the Netherlands, 12 May 2014, case number C/09/460540 / KG ZA 14-185.

internetowy Kwartalnik Antymonopolowy i Regulacyjny 2016, nr 8(5) • www.ikar.wz.uw.edu.pl • DOI: 10.7172/2299-5749.IKAR.8.5.1 
Sąd holenderski uznał roszczenie oparte na metodzie szwajcarskiej za roszczenie produktowe i oceniał rzekome naruszenie jako pośrednie ${ }^{22}$, a nie bezpośrednie, co związane było z przyjęciem, że chodzi o dostawę zasadniczego składnika wynalazku. Strony sporu zgadzały się co do twierdzenia, że lek generyczny stanowił zasadniczy element wynalazku.

Holenderski sąd uznał, że pozwana spółka Sun miała wymaganą wiedzę co do możliwości naruszenia patentu i powinna podjąć dodatkowe działania w celu przeciwdziałania naruszeniu patentu. Takie działania obejmują zawiadomienie pośredników i farmaceutów o ograniczonym zastosowaniu leku generycznego, a także zapewnienie, że zostaną podjęte skuteczne środki w celu rozróżnienia między opatentowanym oraz nieopatentowanym zastosowaniu leku, zarówno gdy chodzi o przetargi szpitalne, jak i inne sposoby dostaw leku.

\section{Ocena orzeczeń w świetle systemu refundacyjnego}

Należy podkreślić, że w obu sprawach znacząco odmienne były okoliczności stanu faktycznego. W szczególności ilość leku generycznego dostarczanego przez Sun w sprawie holenderskiej wykraczała znacznie poza ilość potrzebną do leczenia choroby Pageta na rynku holenderskim. Ponadto Sun zawarł umowę na dostarczenie kwasu zoledronowego do pacjentów objętych ubezpieczeniem publicznym, niezależnie od wskazania medycznego. W praktyce więc lek generyczny musiał być stosowany dla leczenia osteoporozy.

Wydaje się jednak, że różnice w rozstrzygnięciu spraw mogły wynikać nie tylko z odmiennego stanu faktycznego, lecz także $z$ odmiennej argumentacji prawnej. Z perspektywy prawa patentowego to uprawniony zarzuca bezpośrednie bądź pośrednie naruszenie patentu przez producentów leków odtwórczych ${ }^{23}$. Zdaniem autora niniejszej publikacji, kluczowe znaczenie ma odmienność systemów ochrony zdrowia obowiązujących w poszczególnych państwach członkowskich UE, co jest szczególnie istotne w kontekście mechanizmu dostarczania leków do szpitali oraz działań podejmowanych przez lekarzy i farmaceutów skutkujących faktyczną dostępnością leków dla pacjentów.

Warto podkreślić, że sąd angielski zaznaczył współzależność prawa patentowego oraz systemu refundacyjnego. Zwrócił się do angielskich oraz walijskich organów ochrony zdrowia z wnioskiem o wydanie wytycznych dotyczących preskrypcji leków. Zgodnie z aktualnymi wytycznymi British National Formulary skierowanymi do lekarzy, na receptach powinny być używane nazwy międzynarodowe leków (nazwy substancji czynnych) w celu umożliwienia wydania jakiegokolwiek właściwego leku, aby ograniczyć opóźnienia w dostarczeniu leku pacjentowi oraz ograniczyć wydatki na ochronę zdrowia. Jedyny wyjątek dotyczy sytuacji, gdy pojawia się udowodniona różnica w skuteczności klinicznej pomiędzy wersjami leków pochodzącymi od różnych wytwórców. W takim przypadku pacjent powinien otrzymywać konkretny lek, a nie jego zamiennik.

Znamienna jest tu odmienność polskiego prawa refundacyjnego. Zasadą w Polsce jest bowiem przepisywanie nazw handlowych leków na receptach przez lekarzy (co powinno ograniczać substytucję), a jednak na substytucję bezpośredni wpływ może mieć farmaceuta w aptece. W czasach poszukiwania przez publicznych płatników oszczędności, trudno sobie zresztą wyobrazić

\footnotetext{
22 O zakazie pośredniego naruszania wynalazku w systemie niemieckim i angielskim - por. Nowicka, (2014, s. 91).

23 Trzeba zastrzec, że w polskim prawie nie ma sformułowanej expressis verbis regulacji pośredniego naruszenia patentu (zob. Nowicka, 2014, s. 91; Podrecki, 2010, s. 166-168; Stec, 2007, s. 438, odwołujący się do możliwości powołania art. 422 k.c.).
}

internetowy Kwartalnik Antymonopolowy i Regulacyjny 2016, nr 8(5) • www.ikar.wz.uw.edu.pl • DOI: 10.7172/2299-5749.IKAR.8.5.1 
wprowadzenie w całej UE obowiązku przepisywania nazw handlowych leków, uzasadniając to faktem obowiązywania systemu patentowego. Doprowadziłoby to do zwiększenia kosztów refundacji nieuzasadnionego względami medycznymi, mając na uwadze, że rezultaty kliniczne leków mogą być identyczne. Niezależnie od powyższego, trzeba zaznaczyć, że w praktyce w Polsce dochodzi do wymuszania zamiany (tzw. switch) na etapie przetargów publicznych. Szpitale są po prostu zainteresowane nabywaniem jak najtańszych leków, a lekarze i pacjenci muszą się do tego dostosować.

Wydaje się racjonalne, aby wytwórcy leków oryginalnych, w sytuacji zaistnienia ryzyka bezpośredniego bądź pośredniego naruszenia przysługujących im patentów na drugie zastosowanie medyczne, mogli uzgadniać z producentami leków odtwórczych, jakie środki ochronne i działania należy podjąć w celu zminimalizowania ryzyka naruszenia patentu. Istotną rolę odgrywa tu edukacja pracowników ochrony zdrowia, że dany lek jest jedynym legalnie dostępnym na rynku, gdy chodzi o poszczególne wskazanie medyczne. Jednocześnie, z punktu widzenia barierą dla podjęcia tych działań edukacyjnych może być w Polsce stosowana restrykcyjnie przez polskie organy regulacja o reklamie leków. W ocenie autora niniejszej publikacji rozważyć należy skorzystanie z wyłączeń spod pojęcia reklamy, o których mowa w art. 52 ust. 2 prawa farmaceutycznego.

\section{Wnioski}

Zasadniczym celem niniejszej publikacji było podkreślenie współzależności między prawem patentowym oraz systemem refundacyjnym na tle przypadku naruszenia patentu na drugie zastosowanie medyczne. Poszukiwanie kolejnych zastosowań medycznych znanych substancji jest coraz ważniejszym elementem strategii naukowo-badawczej przedsiębiorców farmaceutycznych. Intensywnie rozwija się rynek leków biologicznych, których ceny są znacznie wyższe niż ma to miejsce w przypadku leków chemicznych (Iwanowski, 2015, s. 193), co również wpływa na zwiększenie skali zamiennictwa, w szczególności gdy chodzi o przetargi szpitalne. Ponadto wejście w życie systemu jednolitego patentu unijnego spowoduje znaczący wzrost liczby patentów (Nowicka, 2014, s. 89). Powyższe okoliczności oznaczają, że konieczne staje się doprecyzowanie współzależności między własnością przemysłową a systemem refundacyjnym ${ }^{24}$. W interesie wszystkich uczestników obrotu, włączając w to także lekarzy oraz farmaceutów, jest wyjaśnienie dopuszczalnych granic przepisywania oraz zamiennictwa leków, których substancje są objętymi patentami.

Nie wydaje się celowe przyjęcie zasady, że ograniczenie dostępności zamienników w zakresie drugiego zastosowania medycznego objętego patentem stanowi przejaw nadużycia patentu. Prowadzić to może do niezasadnionego ograniczenia efektywności prawa patentowego w Polsce ${ }^{25}$. Odejście od metody szwajcarskiej formułowania zastrzeżeń patentowych zarówno w europejskim, jak i w polskim prawie patentowym jest potwierdzeniem, że mamy do czynienia z normalnym wynalazkiem. Zamiast tego należałoby raczej rozważyć dostosowanie systemu refundacyjnego do prawa patentowego, w szczególności w aspekcie przepisywania i zamiennictwa leków. Nie oznacza to, że pomiędzy prawem własności intelektualnej oraz systemem refundacyjnym istnieje

\footnotetext{
24 Postulaty te wpisują się w potrzebę reform w dziedzinie prawa patentowego w kontekście innowacji, o których pisze S. Sołtysiński (2014, s. 175-177). Por. także zalecenia R. Skubisza (2014, s. 155-156).

25 Na tle federalnego prawa amerykańskiego por. Burchfiel (1991, s. 107).
} 
sprzeczność. Cele są podobne - chodzi o zapewnienie dostępu do leków, co ma niebagatelne znaczenie dla rozwoju technologii medycznych, a znajdowanie kolejnych zastosowań medycznych znanych substancji jest przecież równie ważne co odkrywanie nowych substancji czynnych.

Nie można zapominać o tym, że celem prawa patentowego jest pobudzanie innowacyjności, także gdy chodzi o poszukiwanie nowych zastosowań medycznych znanych substancji (Rutkowska, 2013, s. 117, 119, 138). Warto też podkreślić, że jednym ze znaczących celów Unii Europejskiej jest wspieranie innowacji (art. 173 ust. 1 TFUE). System patentowy jest jednym z ważnych instrumentów polityki gospodarczej. Potrzeba takiej zachęty opiera się na przekonaniu, że w gospodarce rynkowej poziom innowacji, czyli wytwarzania wiedzy nie jest optymalny (Demaret, 1978, s. 3). W polskiej literaturze dominuje tymczasem krytyka wobec przyjęcia jednolitych standardów ochrony własności przemysłowej, ze szczególnym natężeniem skierowana względem TRIPS oraz patentowania leków (zob. Sołtysiński. O potrzebie reformy prawa patentowego, s. 1045-1046; Correa, 1998, s. 75-100).

Trzeba wreszcie zwrócić uwagę na aspekt transgraniczny prawa patentowego. Ma ono wymiar międzynarodowy. Mimo terytorialnego zasięgu ochrony, znaczenie patentów jest globalne, ze względu na obowiązywanie systemu konwencji międzynarodowych, o zasięgu regionalnym i ogólnoświatowym (Aplin i Davis, 2013, s. 534-543). Okoliczności te muszą być brane pod uwagę przy określaniu zakresów wyłączności prawnej wynikającej z patentu na drugie zastosowanie medyczne.

\section{Bibliografia}

Aplin, T. i Davis, J. (2013). Intellectual Property Law. Text, Cases and Materials. Second Edition. Oxford: Oxford University Press, s. 615-619.

Burchfiel, K. (1991). Patent Misuse and Antitrust Reform: "Blessed be the tie?". Harvard Journal of Law \& Technology, vol. 4.

Cook, T. (2016). Pharmaceuticals, Biotechnology and the Law. London: LexisNexis/Butterworths.

Correa, C.M. (1998). Implementing the TRIPS Agreement in the patents field: options for developing countries. The Journal of World Intellectual Property, 1(1).

Demaret, P. (1978). Patents, Territorial Restrictions, and EEC Law. A Legal and Economic Analysis. IIC Studies. New York: Verlag Chemie.

Grabowski, H. (2002). Patents, Innovation and Access to New Pharmaceuticals. Journal of International Economic Law, 5(4).

Iwanowski, P. (2015). Badania kliniczne leków biopodobnych. W: T. Brodniewicz (red.), Badania kliniczne. Warszawa: CeDeWu.

Jacek, A. (2013). System refundacji leków, środków spożywczych specjalnego przeznaczenia żywieniowego oraz wyrobów medycznych w Polsce. W: K. Mełgieś, K. Miaskowska-Daszkiewicz (red.), Produkt leczniczy - aktualne problemy prawne. Warszawa: Wydawnictwo Medical Communications Sp. z o.o.

Katzka, A. (2008). Interpretation of the term product in EU Council regulation 1768/92 and 1610/96 on Supplementary Protection Certificates. Journal on Intellectual Property Law \& Practice, 3(10).

Kovacic, W. (2005). Competition Policy and Intellectual Property: Redefining the Role of Competition Agencies. W: F. Leveque, H. Shelanski (red.), Antitrust, patents an copyright. EU and US Perspectives. Cheltenham: Edward Elgar Publishing.

Lanjouw, J. (2002). A New Global Patent Regime For Diseases: U.S. And International Legal Issues. Harvard Journal of Law \& Technology, 16. 
Nowicka, A. (2004). Dodatkowe prawo ochronne na produkty lecznicze. Zeszyty Naukowe Uniwersytetu Jagiellońskiego, 88.

Nowicka, A. (2009). Dodatkowe prawo ochronne. Studia Prawa Prywatnego, 3-4.

Nowicka, A., Ochrona innowacji farmaceutycznych. W: M. Kępiński, A. Nowicka, J. Barta (red.), Prawo prywatne czasu przemian. Księga pamiątkowa dedykowana prof. S. Sołtysińskiemu. Poznań: Wydawnictwo UAM.

Nowicka, A. (2014). Wynalazki i ich ochrona - wybrane aspekty prawne i praktyczne. Zeszyty Naukowe Uniwersytetu Jagiellońskiego, Prace z Prawa Własności Intelektualnej, 4.

Pacud, Ż. (2013). Dodatkowe świadectwo ochronne produkty lecznicze w orzecznictwie Trybunału Sprawiedliwości UE i sądów państw członkowskich UE. W: A. Matlak i SA. tanisławska-Kloc (red.), Spory o własność intelektualną. Księga jubileuszowa dedykowana Profesorom Januszowi Barcie i Ryszardowi Markiewiczowi. Wolters Kluwer, wyd. 1.

Pacud, Ż. (2013). Ochrona patentowa produktów leczniczych. Warszawa: LEX a Wolters Kluwer business.

Pieklak M., Stankiewicz R., Czarnuch M., Mądry M. (2014), (przyp. 9), komentarz do art. 11. W: R. Stankiewicz i M. Pieklak (red.), Ustawa o refundacji leków, środków spożywczych specjalnego przeznaczenia żywieniowego oraz wyrobów medycznych. Komentarz. C.H. Beck. Legalis/el.

Podrecki, P. (2010). Środki ochrony praw własności intelektualnej. Warszawa: LexisNexis.

Rubinfeld, D. i Maness, R. (2005). The Strategic Use of Patents: Implications for Antitrust. W: F. Leveque, H. Shelanski (red.), Antitrust, patents an copyright. EU and US Perspectives. Cheltenham: Edward Elgar Publishing.

Rutkowska, S.M. (2013). Reforma prawa patentowego w USA - system patentowy XXI w.? Zeszyty Naukowe Uniwersytetu Jagiellońskiego, Prace z Prawa Własności Intelektualnej, 4.

Sikorski, R. (2014). Aktualne zagadnienia na styku własności intelektualnej i prawa konkurencji Unii Europejskiej. Zeszyty Naukowe Uniwersytetu Jagiellońskiego, Prace z Prawa Własności Intelektualnej, 4.

Skubisz, R. (2014). Polskie prawo własności przemysłowej (stan obecny i perspektywy zmian). Zeszyty Naukowe Uniwersytetu Jagiellońskiego, Prace z Prawa Własności Intelektualnej, 4.

Sołtysiński, S. (2014). O niektórych aspektach ochrony własności intelektualnej i szansach poprawy innowacyjności polskiej gospodarki: refleksje agnostyka. Zeszyty Naukowe Uniwersytetu Jagiellońskiego, Prace z Prawa Własności Intelektualnej, 4.

Sołtysiński, S. (2013). O potrzebie reformy prawa patentowego. W: A. Matlak i A. Stanisławska-Kloc (red.), Spory o własność intelektualną. Księga jubileuszowa dedykowana Profesorom Januszowi Barcie i Ryszardowi Markiewiczowi. Wolters Kluwer, wyd. 1.

Stec, P. (2007). Zasady i funkcje odpowiedzialności z tytułu naruszenia własności intelektualnej. Kwartalnik Prawa Prywatnego, 2.

Szczepanowska-Kozłowska, K. (2015). W: E. Nowińska, K. Szczepanowska-Kozłowska (red.), Prawo własności przemysłowej. System Prawa Handlowego. Tom 3. Warszawa: C.H. Beck.

Żakowska-Henzler, H. (2001). Wynalazki dotyczące drugiego medycznego zastosowania na gruncie Europejskiej Konwencji Patentowej oraz ustawy Prawo własności przemysłowej - wybrane zagadnienia. Rzecznik Patentowy, 3. 